\title{
Online E-Campus Interview Training MOOC Framework for Graduates
}

\author{
Varun Shenoy, P. Sridhara Acharya, \& P. S. Aithal
}

Srinivas Institute of Management Studies, Srinivas University, Mangalore - 575 001, INDIA E-mail: varun_shenoy@rediffmail.com

Type of the Paper: Research Case Study.

Type of Review: Peer Reviewed.

Indexed In: OpenAIRE.

DOI: https://doi.org/10.5281/zenodo.1493263.

Google Scholar Citation: IJCSBE

\section{How to Cite this Paper:}

Shenoy, Varun, Sridhara Acharya, P. \& Aithal, P. S. (2018). Online E-Campus Interview Tranining MOOC Framework for Graduates. International Journal of Case Studies in Business, IT and Education (IJCSBE), 2(2), 53-60.

DOI: https://doi.org/10.5281/zenodo.1493263.

International Journal of Case Studies in Business, IT and Education (IJCSBE)

A Refereed International Journal of Srinivas University, India.

(C) With Authors.

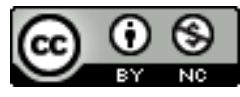

This work is licensed under a Creative Commons Attribution-Non Commercial 4.0 International License subject to proper citation to the publication source of the work.

Disclaimer: The scholarly papers as reviewed and published by the Srinivas Publications (S.P.), India are the views and opinions of their respective authors and are not the views or opinions of the S.P. The S.P. disclaims of any harm or loss caused due to the published content to any party. 


\title{
Online E-Campus Interview Training MOOC Framework for Graduates
}

\author{
Varun Shenoy, P. Sridhara Acharya, \& P. S. Aithal \\ Srinivas Institute of Management Studies, Srinivas University, Mangalore - 575 001, INDIA \\ E-mail: varun_shenoy@rediffmail.com
}

\begin{abstract}
Currently, academic MOOC (Massive Open Online Courses) is widely recognized as a major step in disruptive innovations that is taking place in Higher Education sector today. Simulative MOOC is also adopted in corporations for staff or personnel trainings for cutting down training costs and time at Industry. Moreover, with E-HRM also partially disrupting orthodox HR Processes at Industry level, Online E-Campus Interviews have also become more immensely evident towards graduate hiring presently. Therefore, training job seeking graduates for achieving success in current online interviews in this regard too has also become a very paramount challenge for training \&placement services cell of educational institutions. Therefore, as a solution, this paper attempts to construct a very basic simulative MOOC prototype framework with a very comprehensive online interview training contents which we feel shall benefit all the stakeholders involved. Accordingly, possible sample contents, materials, and syllabus are formulated for developing into a full-fledged online etraining \& learning platform for further studies.
\end{abstract}

Keywords: E-Campus Interview Training, MOOC Training for Online Interviews, Online Interview Training, Skill Development Training, Vocational MOOC.

\section{INTRODUCTION :}

Present days in industry recruitment or selection processes is the foreplay of E-HRM in the limelight. E-HRM refers to widespread usage \& application of electronic methodologies, digital platforms plus cutting-edge technologies plus World Wide Web internet to social media in candidate recruitment process. E-HRM is significantly influencing campus recruitment processes at business schools presently and is expected to be recognized as a standard single running procedure or format to be followed in future by campus recruiters with rapid development in Automation, Robotics, Artificial Intelligence Technology as well as Internet of Things (IoT) or any other revolutions in digital world. This E-HRM powered process is identified as online e-campus interview/placement/recruitment at management institutions. Apparently, Industry in this regard is expecting the Training \& Placement teams at business schools to train the students to confront or interface E-HRM process powered online e-campus interviews in the days coming to up-skill the campus student talent pool for their career prospects in Industry. A graduate to employee transition process for students should ensure consonance and harmony in the aspects of student evaluation, training and placement [1]. Educational Institutions in this regard of digitizing the training \& placement process to match the E-HRM Innovations at Industry did set-up web portals to automate their processes investing required resources [2-7]. Research Studies on applicant reactions to systems and technologies presented the responses of candidates in digital setup towards advancement [8-9]. Papers examined on E-HRM also fortified the positive mileage of technology based HR processes [10-11]. However, with the prevailing time limitation obstructing the much-needed Industry Academia congruence in this regard, job seeking students are alienated towards the actual practice of E-HRM at Industries. Thus, to ensure the benefit of job seeking students to be trained on the requirement of E-HRM, a BOX Framework for Online ECampus Interview Training was formulated by Shenoy and Aithal (2017) [12]. Therefore, this paper attempts to develop another Framework for Online E-Campus Interview training through MOOC (Massive Open Online Course) towards job seeking students at campus and also for the benefit of 
industry. The framework along with its detailed required expected criterions will be presented before the stakeholders in this study.

\section{OBJECTIVES OF THE STUDY :}

The main objective of this paper is to develop a robust student e-placement training MOOC (Massive Online Open Course) blueprint for placement success at E-HRM powered Online E-campus interview. The aim under the framework here is to propose a digital platform where MOOC can be hosted as well as the online e-interview training contents uploaded into the MOOC. Secondary purpose of the study also seeks that framework constructed if bought into reality will serve as a basic level training extension of E-HRM Industry requirements at graduate education campuses. Final aim is that the study will focus on efforts made to bridge the gap between Industry and Academia.

\section{RESEARCH METHODOLOGY :}

The Information gathering process required to develop the sample framework was divided into a twostep process. Firstly, to construct the online e-training components expected in the MOOC framework Sample, direct interview method was utilized via field visits and telephonic conversations to gather information from industry recruiters on their expectations from fresh graduates in alignment to EHRM. The technologies used to interview or source the candidates were also discussed. Accordingly, these recruiters formed as a part of head hunters of NIRF (National Institute Ranking Framework India) ranked Top 10 Indian Business Schools. For the second set of data collection, select group of professors from Srinivas College of Computer \& Information Sciences were consulted for the workflow required for constructing the MOOC Server Platform in the framework. The gathered data in afore mentioned methodology is then converted into modular table representation under relevant headings for understanding actual proposal determination and interpretations. The perceived advantages, benefits, constraints and disadvantages from the framework will also be placed in front of the audience.

\section{PROPOSED MOOC FRAMEWORK FOR STAKEHOLDER INTERPRETATIONS :}

Based upon collected data and intended plan, the recommended MOOC framework for training students for online e-campus interview facing preparations is expected to be conceptualized as per Table 1 - Table 3.

Table 1 :Basic proposed Component Architecture of expected Online E-Campus Interview Training MOOC :

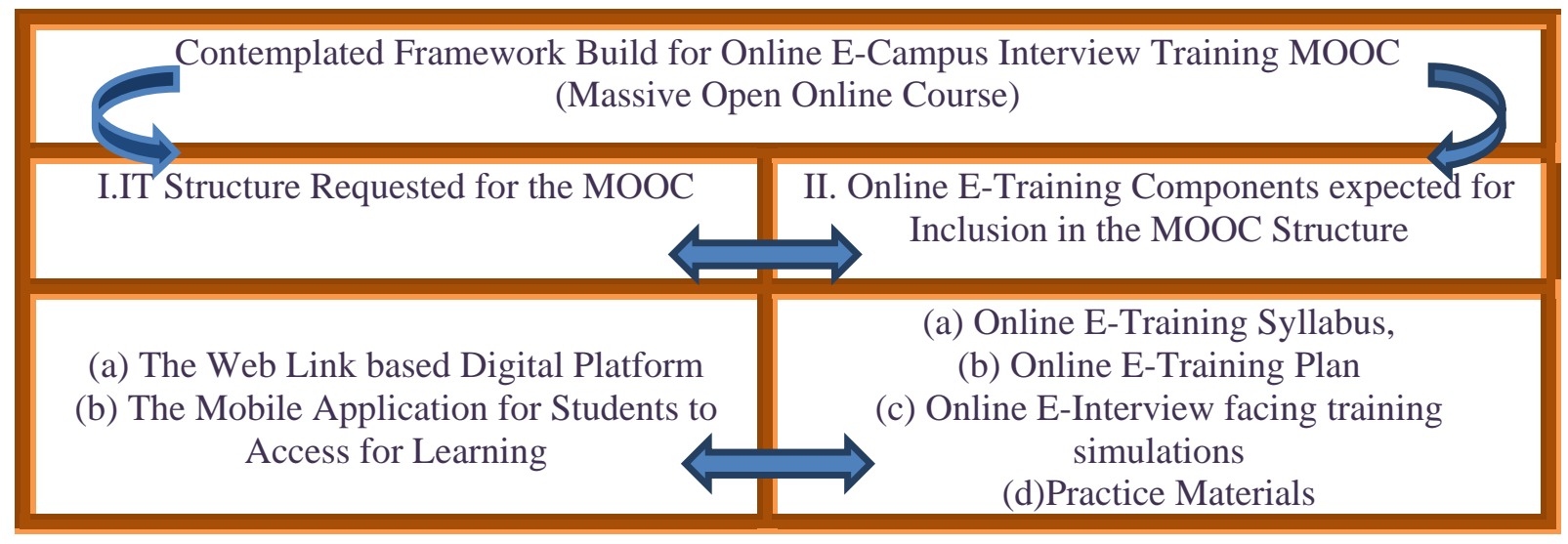


Table 2 : Detailed IT Structure SegregationBuild expected for the proposed MOOC

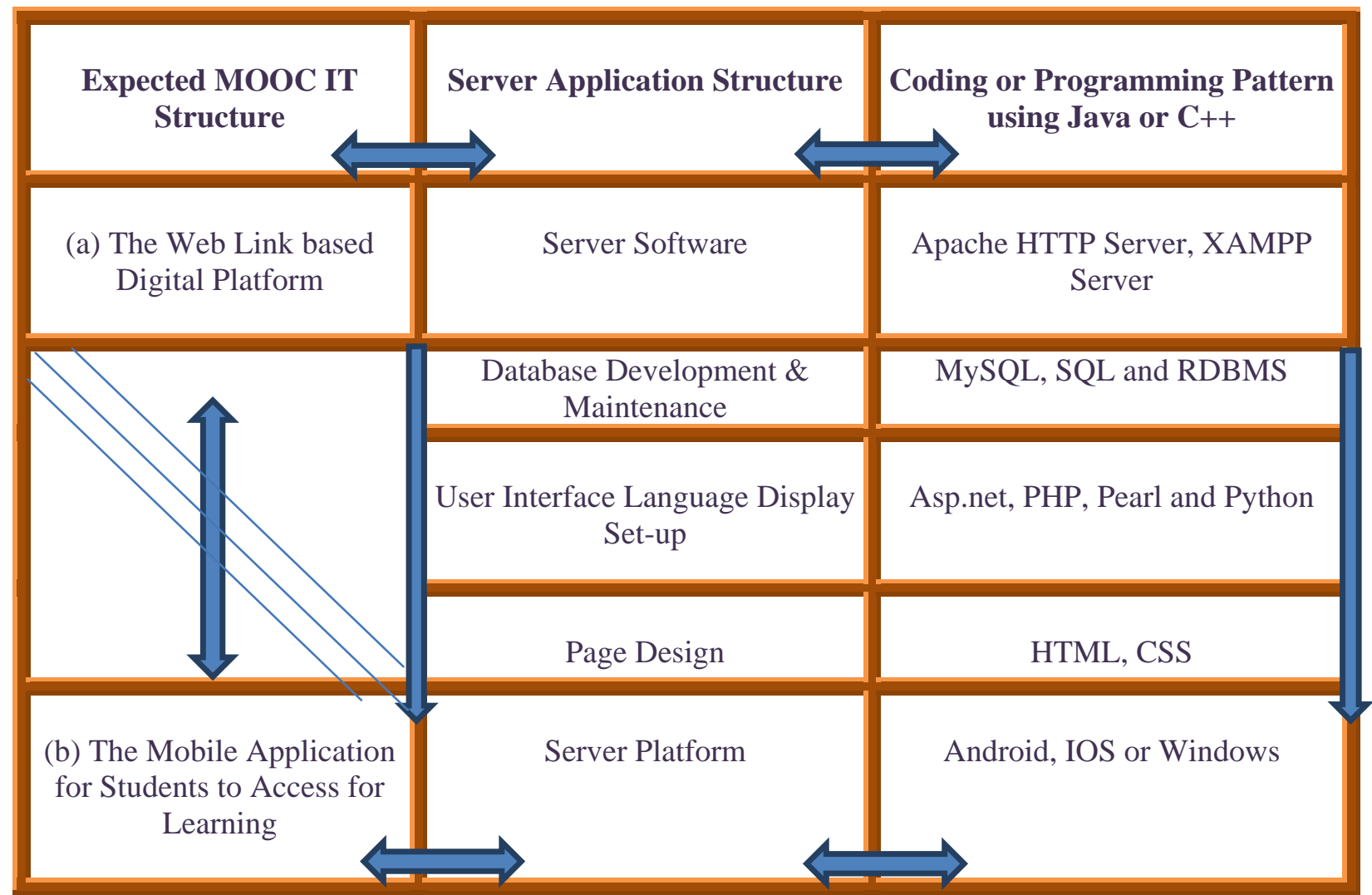

Table 3 :DetailedSegregation of Online E-Training Components expected for Inclusion in the MOOC Structure

\begin{tabular}{|c|c|}
\hline $\begin{array}{l}\text { Online E-Training } \\
\text { Components expected } \\
\text { for Inclusion in the } \\
\text { MOOC IT Structure }\end{array}$ & $\begin{array}{c}\text { Sample } \\
\text { Components }\end{array}$ \\
\hline $\begin{array}{c}\text { (a) Online E-Training } \\
\text { Syllabus, }\end{array}$ & $\begin{array}{c}\text { Detailed Unit-wise } \\
\text { plan structure with } \\
\text { Training Objectives, } \\
\text { Purpose, } \\
\text { Components, } \\
\text { Training Pedagogy }\end{array}$ \\
\hline $\begin{array}{l}\text { (b) Online E-Training } \\
\text { Plan }\end{array}$ & $\begin{array}{c}\text { Session Wise Units } \\
\text { with relevant topics, } \\
\text { time hours, practical } \\
\text { aspects, reference } \\
\text { websites, links and } \\
\text { so on }\end{array}$ \\
\hline
\end{tabular}




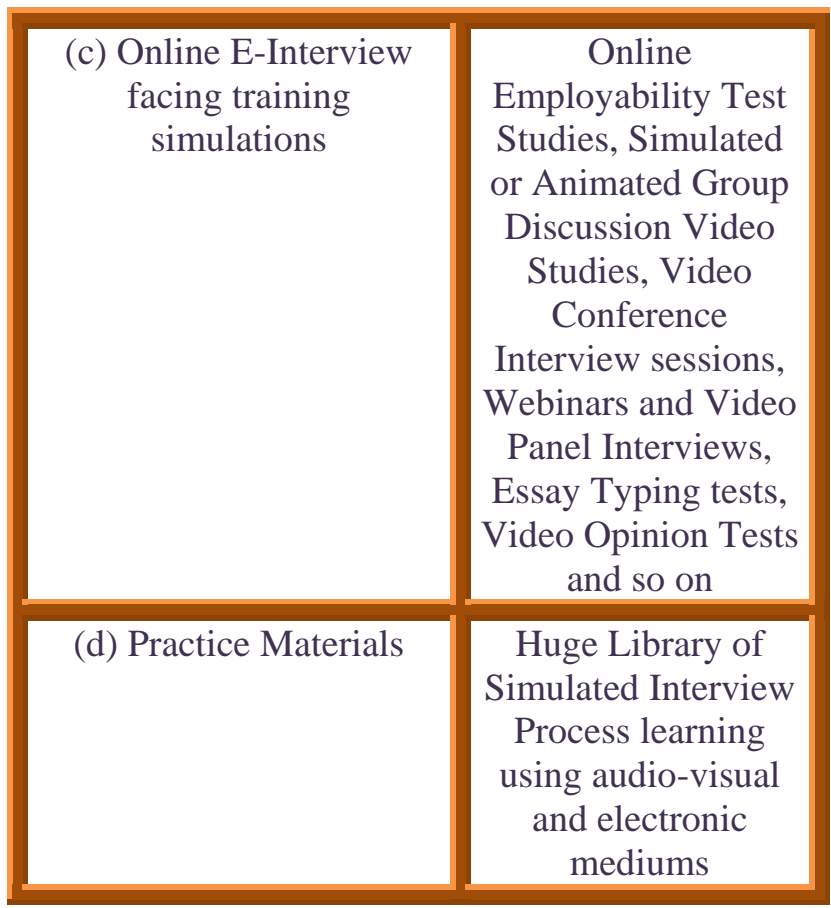

As discussed in the Table 1 above, the primary proposal for constructing a robust Online E-Campus Interview Training Model can be categorized into (a) The Digital Platform where course will be hosted and (b) Actual Training Contents.

Table 2 and Table 3 details the complete expected construction builds for the prototype framework. However, to realize this idea into reality for the benefit of placement success of students at online einterviews, stakeholders are requested to develop interest for employing the required personnel, facility, key resources, capital and time as a project for bringing the portal into reality. The inventors would be happy for Patent Agreements and Knowledge expertise sharing. Interested Students could also take this idea up to develop into a full-fledged platform through start-up initiatives.

\section{ABCD LISTING OF THE PROPOSED MOOC FRAMEWORK :}

The proposed Online E-Campus Interview training framework is evaluated through ABCD Analysis's listing technique developed by Aithal et.al (2015) [13-30].

(1)Advantages :

- The framework promotes the spirit of self-learning among students.

- The Model is advantageous for Industry to align their E-HRM Requirements.

(2) Benefits :

- The MOOC enables students to practice from home anytime/anywhere.

- The Framework is a Cash Cow Opportunity for Investors and Companies in product development work space.

(3) Constraints :

- Converting the Framework into working reality is challenge oriented owing to varying requirements of the market player or decision makers.

- Licensing and Patenting Constraints.

(4) Disadvantages :

- Inherently disadvantageous if the framework lacks the required feature as per changing industry trend in the prototype phase.

- Disadvantageous if proposed framework limits its compatibility in sync with existing technologies while converting into an actual product package towards implementation \& practice.

ABCDModelwasdevelopedbyAithaletal.(2015)whoseapplicationresultsinacompleteanalysisofprimeAAdvantages,B-Benefits,C-Constraints,andD-Disadvantagesinanorganizedformat for a Model, Strategy, 
Procedure, Process, Rules or Concepts[14]. Over the years, ABCD Analysis methodology is widely applied to studies in various areas of higher education and business fields like academic/business models, functional areas, strategies, universities and their regulatory authorities [15-30]. The critical constituent elements derived through application of this analysis enabled making informed decisions.

\section{CONCLUSION :}

To summarize this study, we have formulated a sample draft Online E-Placement Training MOOC Framework for facilitating successful student placements at online e-campus interviews. The framework constructed by authors include (a) the digital platform where the MOOC is hosted (b) training contents designed based on information collected from Industry as per E-HRM alignment. Anyways in coming future, inventors of this framework hope this idea can be realized through converting the framework into an actual full-fledged platform for the e-interview training or practice of job seeking students in an E-HRM set-up of today. Inventors also welcome for any further feedback or suggestions from stakeholders interested in the idea to improve the draft or its contents subject to evaluative requirements.

\section{REFERENCES :}

[1] Kosciulek, J. F., Prozonic, L. A., \& Bell, D. (1995). On the congruence of evaluation, training, and placement. Journal of Rehabilitation, 61(4), 20.

[2] Rathod, N., Shah, S., \&Shirsat, K. (2013). An Interactive Online Training \& Placement System. International Journal of Advanced Research in Computer and Communication Engineering, 3(12).

[3] Kasture, H., Saraiyya, S., Malviya, A., \& Bhagat, P. (2014). Training and Placement Web Portal. International Journal on Recent and Innovation Trends in Computing and Communication,2(3).

[4] Shewale, R., Chodhary, P., Powale, S., Chimankar, S., \& Umale, A. (2015). Training and Placement Web Portal. Research Journal of Science and Technology, 7(2), 111.

[5] Neill, N. T., \& Mulholland, G. E. (2003). Student placement-structure, skills and esupport. Education+ Training, 45(2), 89-99.

[6] Collins, S., \& Jerry, P. (2005). The Campus Alberta Applied Psychology Counselling Initiative : Web-based delivery of a graduate professional training program. Journal of Technology in Human Services, 23(1-2), 99-119.

[7] Stadtlander, L. M., \& Giles, M. J. (2010). Virtual instruction: A qualitative research laboratory course. Teaching of Psychology, 37(4), 281-286.

[8] Hella, Sylva., Stefan T. Mol. (2009). E-Recruitment: A study into applicant perceptions of an online application system. International Journal of Selection and Assessment,17(3), pp. 311-323.

[9] Bauer, T. N., Truxillo, D. M., Paronto, M. E., Weekley, J. A. and Campion, M. A. (2004). Applicant Reactions to Different Selection Technology: Face-to-Face, Interactive Voice Response, and Computer-Assisted Telephone Screening Interviews. International Journal of Selection and Assessment, 12(1), pp. 135-148.

[10] Ruël, H., Bondarouk, T., \& Looise, J. K. (2004). E-HRM: Innovation or irritation. An explorative empirical study in five large companies on web-based HRM. Management revue, 364-380

[11] Furtmueller, E., Wilderom, C., \& Tate, M. (2011). Managing recruitment and selection in the digital age: e-HRM and resumes. Human Systems Management, 30(4), 243-259.

[12] Shenoy, Varun., Aithal, P. S. (2017). A New Box Framework for E-Campus Interview Training. International Journal of Applied Engineering and Management Letters (IJAEML), 1(2),17-26. 
[13] Aithal, P. S., Shailashree, V. T., Suresh Kumar, P. M. (2015). A New ABCD Technique to Analyze Business Models \& Concepts, International Journal of Management, IT and Engineering (IJMIE), 5(4), 409-423. DOI: http://doi.org/10.5281/zenodo.61652.

[14] Aithal, P. S. (2016). Study on ABCD Analysis Technique for Business Models, Business strategies, Operating Concepts \& Business Systems, International Journal in Management and Social Science, 4(1), 98-115. DOI : http://doi.org/10.5281/zenodo.161137.

[15] Aithal, P. S., Shailashree, V. T., \& Suresh Kumar, P. M. (2015). Application of ABCD Analysis Model for Black Ocean Strategy. International Journal of Applied Research (IJAR), 1(10), 331337. DOI: http://doi.org/ 10.5281/zenodo.163424.

[16] Aithal, P. S., Shailashree, V. T., \& Suresh Kumar P. M., (2016). ABCD analysis of Stage Model in Higher Education. International Journal of Management, IT and Engineering (IJMIE), 6(1), 11-24. DOI: http://doi.org/10.5 281/zenodo.154233.

[17] Aithal, P. S., Shailashree, V. T., \& Suresh Kumar, P. M. (2016). Analysis of NAAC Accreditation System using ABCD framework. International Journal of Management, IT and Engineering (IJMIE), 6(1), 30-44. DOI: http://doi.org/10. 5281/zenodo.154272.

[18] Aithal, P.S., Shailashree, V. T., \& Suresh Kumar, P. M. (2016). Application of ABCD Analysis Framework on Private University System in India. International Journal of Management Sciences and Business Research (IJMSBR), 5(4), 159-170. DOI :http://doi.org/10.5281/zenodo.161111.

[19] Aithal, P. S., Shailashree, V. T., \& Suresh Kumar, P. M. (2016). The Study of New National Institutional Ranking System using ABCD Framework. International Journal of Current Research and Modern Education (IJCRME), 1(1), 389-402. DOI :http://doi.org/10.5281/zenodo.161077.

[20] Shubhrajyotsna Aithal, \& Aithal, P. S. (2016). ABCD analysis of Dye doped Polymers for Photonic Applications. IRA-International Journal of Applied Sciences, 4 (3), 358-378. DOI: http://dx.doi.org/10. 21013/j as.v4.n3.p1.

[21] Aithal, P. S., Shailashree, V. T. \& Suresh Kumar, P. M., (2016). Analysis of ABC Model of Annual Research Productivity using ABCD Framework. International Journal of Current Research and Modern Education (IJCRME), 1(1), 846-858. DOI :http://doi.org/10.5281/ zenodo.62022.

[22] Varun Shenoy, \& Aithal P. S., (2016). ABCD Analysis of On-line Campus Placement Model. IRA-International Journal of Management \& Social Sciences, 5(2), 227-244. DOI: http://dx.doi.org/10.21013/jmss .v5.n2.p3.

[23] Aithal, P. S., Shailashree V. T. \& Suresh Kumar P.M. (2016). Factors \& Elemental Analysis of Six Thinking Hats Technique using ABCD Framework. International Journal of Advanced Trends in Engineering and Technology (IJATET), 1(1), 85-95. DOI :http://doi.org/10.5281/zenodo.240259.

[24] Aithal, P. S. \& Suresh Kumar, P. M. (2016). CCE Approach through ABCD Analysis of 'Theory A' on Organizational Performance. International Journal of Current Research and Modern Education (IJCRME), 1(1), 169-185. DOI: http://dx.doi.org/10. 5281/zenodo.164704.

[25] Aithal, P. S. (2017). ABCD Analysis of Recently Announced New Research Indices. International Journal of Management, Technology, and Social Sciences (IJMTS), 2(1), 65-76. DOI: http://doi.org/10.5281/ zenodo. 583644.

[26] Aithal, P. S. (2017). Factor Analysis based on ABCD Framework on Recently Announced New Research Indices. International Journal of Management, Technology, and Social Sciences (IJMTS), 1(1), 82-94. DOI: http://dx.doi.org/1 0.5281/zenodo.584105. 
[27] Aithal, P. S., (2017). ABCD Analysis as Research Methodology in Company Case Studies. International Journal of Management, Technology, and Social Sciences (IJMTS), 2(2), 40-54. DOI: http://dx.doi.org/10.5 281/zenodo.891621.

[28] Aithal, Architha., Aithal, P. S. (2017). ABCD Analysis of Task Shifting-An optimum Alternative Solution to Professional Healthcare Personnel Shortage. International Journal of Health Sciences and Pharmacy (IJHSP), 1(2), 36-51. DOI: http://dx.doi.org/10.5281/zenodo.1038975.

[29] Varun Shenoy \& Aithal, P. S., (2017). Quantitative ABCD Analysis of IEDRA Model of Placement Determination. International Journal of Case Studies in Business, IT and Education (IJCSBE), 1(2), 103-113. DOI: http://dx.doi.org/10.5281/zenodo.1133691.

[30] Keerthan Raj, \& Aithal, P. S. (2018 March). Generating Wealth at the Base of the Pyramid - A Study using ABCD Analysis Technique. International Journal of Computational Research and Development (IJCRD), 3(1), 68-76. DOI :http://doi.org/10.5281/zenodo.1205586. 